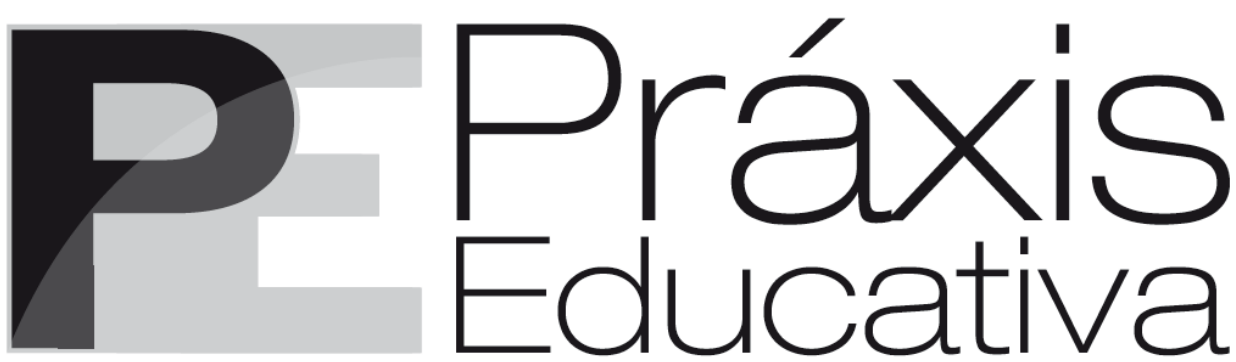

ISSN 1809-4309 (Versão online)

DOI: 10.5212/PraxEduc.v.11i2.0002

\title{
No meio do mundo, aquendar a metodologia: notas para queerizar a pesquisa em currículo
}

\section{In the middle of the world, aquendar the methodology: notes for queering curriculum research}

\section{En el meio del mundo, aquendar la metodología: notas para queerizar la investigácion en curriculum}

Thiago Ranniery Moreira de Oliveira*

Resumo: Este artigo investiga como a condição da crítica queer não se reflete apenas na esfera do intercâmbio social, mas pode adquirir dimensões metodológicas a tal ponto de permitir reaplicar às posturas investigativas e aos itinerários de pesquisa em currículo o estilo irônico e jocoso de ressignificação do insulto queer. $\mathrm{O}$ argumento explorado é que a crítica queer permite questionar as naturalizações normativas dos processos de investigação em currículo como aquelas contidas nas fórmulas que tendem a opor pesquisador/pesquisado, realismo/ficção, coerência/multiplicidade. Na perspectiva de tomar o queer como uma leitura heterogênea, este texto explora como quatro apontamentos, combinações, andanças, afetações e fecundações, intentam traduzir o que acontece quando se aquenda a metodologia de pesquisa. Movimentos que podem ser vistos como experimentos errantes em relação ao paradigma da crítica queer em educação e em currículo.

Palavras-chave: Metodologia queer. Localização. Pesquisa em currículo.

Abstract: This paper investigates how the condition of queer critique not only reflects in the sphere of social exchange, but it can acquire methodological dimensions to the extent that allows reapply to the investigative positions and the paths of curriculum research ironic and jocular style redefinition of the queer insult. The explored argument is that the queer critique allows to question the normative naturalization of research procedures into the curriculum as those contained in the formulas that tend to oppose researcher/researched, realism/fiction, coherence/multiplicity. From the perspective of taking queer as a heterogeneous reading, this text explores how four notes, combinations, wanderings, affectations and fertilizations, translate what happens when queering research methodology. Movements that can be seen as wandering experiments in relation to the paradigm of queer critique in Education and curriculum.

Keywords: Queer methodology. Localization. Curriculum research.

Resumen: Este artículo investiga cómo la condición de crítica queer se refleja no sólo en la esfera del intercambio social, sino que puede lograr dimensiones metodológicas al punto que permita que se vuelva a aplicar las posturas investigativas y a los caminos de investigación en currículum, el estilo irónico y jocoso

\footnotetext{
* Professor da Universidade Federal do Rio de Janeiro (UFRJ). Doutorando em Educação - Universidade do Estado do Rio de Janeiro (UERJ). E-mail: <t.ranniery@gmail.com>.
}

Práxis Educativa, Ponta Grossa, v. 11, n. 2, p. 332-356, maio/ago. 2016 Disponível em: <http://www.revistas2.uepg.br/index.php/praxiseducativa $>$ 
de redefinición del insulto queer. El argumento explorado es que la crítica queer permite cuestionar las naturalizaciones normativas de los procesos de investigación en currículum como aquellas contenidas en las fórmulas que tienden a oponer investigador/investigado, realismo/ficción, coherencia/multiplicidad. Desde la perspectiva de tomar queer como una lectura heterogénea, este texto explora cómo las cuatro notas, combinaciones, andanzas, afectaciones y fertilizaciones, intentan traducir lo que sucede cuando se aquenda la metodología de investigación. Movimientos que pueden ser vistos como experimentos errantes en relación al paradigma de la crítica queer en la educación e en currículum.

Palabras-clave: Metodología queer. Localización. Investigación en currículum.

Lá estava, às vésperas da viagem para a realização da pesquisa de campo, descobrindo, à contrapelo, ou voltando, de algum modo, a me deparar com aquela necessidade de escrever um capítulo explicando minhas escolhas e meus itinerários de pesquisa. Será que eu sei mesmo por que escolhi este caminho ou não? Será que tenho razões aceitáveis para explicar por que eu segui deste modo e não de outro? Ansioso por encontrar com sujeitos de pesquisa, interlocutores, com os quais já havia mantido contato por rede social, precisei lidar com uma espécie de herança da pesquisa da educação. Como assim você vai para Aracaju? O que tem lá? Você vai para as escolas? Explica: por que sua pesquisa é em currículo? Esta não foi apenas uma viagem entre estados e aeroportos ${ }^{1}$, mas entre fatias de mundos. Lembro-me, assim, das horas atravessando, de ônibus, atolado nas ruas pelo trânsito, em direção a suas periferias, a pequena capital de Aracaju, literalmente e abruptamente perdido no meio do mundo, como chamou um de seus mais famosos contistas 2 : a ignorância do destino e a urgência da empreitada. (Trecho do diário de campo).

Para quem se dedica a tarefa da pesquisa, sempre chega aquele momento, de um modo ou de outro, quase impossível de escapar: descrever como realiza a prática de investigação a qual se dedica. Haber (2011) relembra como a etimologia da palavra investigação remonta a uma ideia que é cara a metodologia de pesquisa: marca que deixa sua inscrição em algum lugar. Por investigação, é possível entender, portanto, algo como seguir trilhas, pistas e rastros. De fato, se olharmos para qualquer manual de introdução à pesquisa em educação, encontraremos valiosas recomendações para encaminhar uma investigação. A incorporação dos estudos queers para uma pesquisa em gênero, sexualidade e currículo, levada a cabo em uma pequena capital, Aracaju, Sergipe, começou a me sugerir, no entanto, que não poderia antecipar as rotas seguras dos manuais de introdução à metodologia. Só poderia segui-las e, com efeito, essas rotas só existiam na medida em que as trilhava. Nem podia sequer prever que chegaria a algum destino em particular, somente saber que intentei seguir algumas pistas, onde quer que me levassem, inclusive a lugar nenhum. Essa imagem das trilhas serve-me para apontar pequenas pistas em torno das possibilidades de queerizar - uma designação esquisita, diga-se desde já - caminhos de investigação em currículo, gênero e sexualidade, a partir dos itinerários de um trabalho de pesquisa que se apresenta mais difuso, confuso e plural do que se poderia esperar.

Há, entretanto, a introdução de um fator complicador: dentre as inúmeras perspectivas pós-estruturais ${ }^{3}$, compartilha-se um sentimento de desconforto a respeito das respostas que se

\footnotetext{
${ }^{1}$ A pesquisa que subsidia este artigo contou com bolsa de doutorado do CNPq entre 2013 e 2014 e, desde 2015, conta com financiamento do programa Bolsista Nota 10 da Fundação de Apoio à Pesquisa do Estado do Rio de Janeiro (Faperj). Agradeço à Elizabeth Macedo, aos membros do grupo de pesquisa em Currículo e Diferença (Proped/UERJ) pelas diversas oportunidades em discutir muitos dos pontos que se seguem.

${ }^{2}$ Refiro-me ao conto No meio do mundo de Antônio Carlos Viana (1999).

3 Escaparia dos propósitos deste texto uma apresentação pormenorizada do que o pós-estruturalismo vem a
}

Práxis Educativa, Ponta Grossa, v. 11, n. 2, p. 332-356, maio/ago. 2016 Disponível em: <http://www.revistas2.uepg.br/index.php/praxiseducativa> 
pode dar às interpelações de como fazemos pesquisa em currículo. Esse fator, que extrapola os manuais disciplinares e as definições etimológicas, insere uma questão insistente: como proceder quando se é confrontado com atores no próprio campo do currículo que não significam metodologia, investigação e pesquisa nos mesmos termos? Ainda que o conflito entre tendências e filiações teóricas não possa ser reduzido facilmente a um mínimo método comum, porque os modos de compreensão da produção de conhecimento em educação evidenciam mais vicissitudes do que similaridades universalizáveis, um esforço é reconhecível para tornar inteligíveis modos de fazer pesquisa em educação quando se elege entrar no âmbito metodológico das perspectivas pós-estruturais ${ }^{4}$. Uma eleição que se caracteriza por ser um tanto perigosa. Ao considerar a sorte da Ciência com o advento do pós-estruturalismo, o discurso dominante tem sido o discurso de catástrofe e da exaustão. Ora, tenta-se um deleite com as consequências apocalípticas de uma forma virulenta de anti-cientificidade. Ora, envolve-se em uma lamentação por aquilo que foi perdido, com frequência entregando-se a uma busca pela restituição da Ciência por meio da sua realocação.

Uma anedota literária pode ser explicativa desta sensação. Refiro-me ao alienista, do livro homônimo de Machado de Assis (1992), que, certa vez, foi indagado por um boticário insatisfeito com a pretensa "revolução" que o personagem queria protagonizar no mundo das ideias médicas. O boticário defendia que "[...] nem todas as instituições do antigo regime mereciam o desprezo do nosso século" (ASSIS, 1992, p. 18). Em contraponto, o alienista respondeu: "Há melhor do que anunciar a minha ideia; é praticá-la" (ASSIS, 1992, p. 18). Desatinados perante a ortodoxia, muitos pesquisadores têm sido vistos como candidatos à Casa de Orates, sobretudo aqueles que, desde pelo menos a primeira década deste século, passaram a figurar uma guinada em face das teorias pós-estruturais que a crescente internacionalização do campo currículo no Brasil suscitou ${ }^{6}$. Boticários e alienistas à parte, não se trata de instaurar uma polêmica, mas, antes, propor outras margens às perspectivas metodológicas; outras margens que não somente as duas da lógica das "alternativas infernais" (PRIGOGINE; STENGERS, 2005). O que une cada uma dessas linhas de significação, segundo Doel (2001), é o fato de que estão baseadas em algum evento negativo que teria ocorrido a uma Ciência abstrata e universal. As impressões do cansaço e das limitações impostas por esse modo de operacionalização da Ciência podem bem funcionar como justificativas possíveis para dizer o quanto seria urgente se aventurar pelos caminhos queers. Todavia, o difícil mesmo torna-se, para retomar Haraway (1995), que uma metodologia qualquer contenha uma explicação da contingência histórica radical sobre todo conhecimento como já parcial e localizado.

O destaque ao loca é proposital. Para assumir uma posição teórica, Ochoa (2004) brinca com o termo que, em muitos países latino-americanos, é usado para se endereçar às "bichas", assim como em muito dos circuitos que pesquisei se usa o "bicha louca", "loka" ou "aloka". Um termo que, segundo La Fountain-Stokes (2011), profundamente latino-americano, dialoga com o pós-estruturalismo e com a contestação queer. Localização permite, pois, atentar para o imbricamento entre a condição de anormalidade e a geografia política de produção do conhecimento. Ali, no meio do mundo, reside um convite a uma leitura queer da investigação em currículo, na qual se procura demarcar uma mudança de estatuto. Se o termo queer permite revelar

significar na pesquisa. Para um maior detalhamento, ver Miller (2010).

${ }^{4}$ A título de exemplo, ver Costa (2002a, 2002b), Costa e Bujes (2005), Peters e Burbules (2004), Meyer e Paraíso (2012).

${ }^{5}$ No livro, O Alienista, o personagem Simão Bacamarte, figura proeminente da cidade de Itaguaí, iniciou o projeto de construção da Casa Verde, a Casa de Orates, local de prática da medicina, onde fazia experiências científicas sobre os aspectos da sanidade e da loucura humanas.

${ }^{6}$ Sobre o processo de internacionalização do campo do currículo, conferir Macedo (2011).

Práxis Educativa, Ponta Grossa, v. 11, n. 2, p. 332-356, maio/ago. 2016 Disponível em: <http://www.revistas2.uepg.br/index.php/praxiseducativa> 
uma mistura de teoria e política na experiência de vida (STRYKER, 2006), sua condição não se reflete apenas na esfera do intercâmbio social. Também pode adquirir dimensões metodológicas a tal ponto que permite reaplicar aos itinerários de pesquisa o estilo irônico e jocoso de ressignificação do insulto queer. Sedgwick (1993, p. 14) propôs, desse modo, que a dimensão performativa do empreendimento queer colocava em cena um uso político e epistemológico "[...] como uma fonte inesgotável de energia transformadora". Que potências podem ser, assim, exploradas dos movimentos queers para a investigação em currículo? É possível uma defesa da experimentação metodológica em currículo? Poderia tal projeto ser desenvolvido não apenas como uma nova abordagem investigativa, mas como meio para reconfigurar as questões metodológicas da pesquisa em currículo?

Inspirado nessa proposição, este texto parte de um sequestro intelectual da expressão aquendar do pajubá. Essa linguagem tem seu léxico produzido no Brasil nos fluxos transatlânticos das línguas nagô e yorubá, e outras línguas de matizes africanas mescladas ao português. Nesse dialeto, certamente não oficial, talvez em virtude mesmo da sua ininteligibidade aos quadros oficiais da linguagem, formas de vidas que escapam a estreiteza da hegemonia heterossexual, o produziram como um modo de estabelecer comunicações e de produzir laços de comunidade. Sua trajetória tanto se direciona contra os mecanismos de poder dos usos straights da linguagem quanto insiste que "[...] queer é sobre o intercruzamento de minorias, nunca foi sobre uma política de identidade" (BUTLER, 2011, p. 209). A plasticidade do pajubá e do termo aquendar articula, assim, experiências e significados de dinâmicas específicas e locais de estigma e vergonha, ao invés de uma tradução direta de queer, em direção ao que defende Ochoa (2004). Nesse percurso, o termo aquendar é também usado neste texto como uma imagem corporal que permite explorar um lugar de enunciação crítica à normatividade da linguagem da pesquisa em currículo e suas ressonâncias nos caminhos de investigação. Ao pensar, segundo Rooke (2010), que os estudos queer não se limitam a abordar subjetividades sexuais e de gênero, mas a discutir sobre qualquer forma de normatividade, incluindo os processos de pesquisa, contestar a gramática e a linguagem nas quais formas de fazer investigação são instituídas e adquirem inteligibilidade é desde já um campo de contestação queer.

Espero demonstrar como o sequestro de aquendar não se dá somente por formular um uso possível de uma linguagem queer na pesquisa em currículo, mas também por articular uma visão queer da linguagem da pesquisa. Embora muito já se tenha escrito sobre como o que é e o que faz crítica e os estudos queers, adoto a perspectiva segundo a qual muito de sua eficácia política depende da sua resistência à definição, uma vez que "[...] quanto mais se aproxima de tornar-se uma disciplina acadêmica, menos queer pode a teoria queer ambicionar a ser" (JAGOSE, 1996, p. 1). Acompanho, aqui, Butler (2008) para quem, como lugar de contestação, o queer deve ser trabalhado para continuar a ser aquilo que nunca é plenamente assumido, mas sempre distorcido e realinhado, apontando para um objetivo político em expansão. Como uma zona de potencialidade, a crítica queer "[...] faculta recursos imensos para a análise, enfrentamento e crítica da normatividade, recursos calibrados, precisamente, na medida em que o 'queer' se apresenta como catacrese, como metáfora sem referente adequado" (VILLAREJO, 2005, p. 6970, grifo do autor). Pode o queer, ssa leitura torcida do mundo, potencializar a pesquisa em currículo? Nessa perspectiva, exploro, a seguir, quatro apontamentos para uma possível queerização da investigação em currículo. Combinações, andanças, afetações e fecundações intentam traduzir, portanto, o que acontece quando se aquenda a metodologia de pesquisa.

Esses movimentos podem ser vistos como experimentos errantes em relação ao paradigma da crítica queer em currículo. Entre eles, ecoa a pergunta de Colebrook (2009): seria a teoria queer

${ }^{7}$ Sobre a reapropriação do termo queer, conferir, a título de sugestão, a sessão final de Butler (2008).

Práxis Educativa, Ponta Grossa, v. 11, n. 2, p. 332-356, maio/ago. 2016 Disponível em: <http://www.revistas2.uepg.br/index.php/praxiseducativa $>$ 
uma reflexão sobre o que significa ser queer ou a reflexão queer muda os modos nos quais teorizamos? De modo análogo, a teoria queer funciona como uma reflexão sobre metodologia ou muda os modos de pesquisar? Meu argumento é que a crítica queer permite desmontar e questionar as naturalizações normativas dos processos de investigação em currículo como aquelas contidas nas fórmulas que tendem a opor pesquisador/sujeito de pesquisa, realismo/ficção, coerência/multiplicidade. Quando Clifford (1997) propõe que olhemos o terreno como local leia-se itinerário em vez de delimitação espacial - de encontros, de viagens, de negociações e de contatos, encontro pistas para traçar uma possível resposta para uma futuridade queer, fazendo um uso um tanto livre da expressão de Munoz (2009), da investigação em currículo. E, assim, se for possível levantar uma escora, ainda que frágil, começo por admitir que qualquer metodologia é construída no processo de investigação e de acordo com as necessidades interpeladas pelo que chamamos objeto de pesquisa e pelos modos de operação teóricas. Afinal, como argumenta Boellstorff (2010), quando se fala de metodologia queer, teoria, dados e métodos não podem ser entendidos de forma isolada uns dos outros, e a relação entre eles constitui um problema metodológico.

\section{Das combinações}

Aquendar, um destes termos dos circuitos de sociabilidade com os quais estive, pode ser um potente mote para oferecer a experiência de uma metodologia queer. As palavras de uma jovem travesti enquanto me explicava sobre o ato aquendar podem ser indicativas: é o ato de se olhar no espelho com o pau entre as pernas, deixando à mostra um tufo macio de pentelhos, além de render fotos maravilhosas, claro. Só que, para algumas, a graça de fingir não ter um pênis nunca acaba. Essa tensão entre segredo e transformação, que permite retomar, sob outra ótica, o debate epistemológico proposto por Sedgwick (1990), pode bem funcionar como uma imagem do pensamento para queerização da investigação em currículo. Enquanto assistia ao ato de aquendar, observei que a ação de transformar a genitália masculina em uma aparente genitália feminina a partir de um conjunto de técnicas e procedimentos indicavam simultaneamente uma rotina repetida e um aparato de improvisação. Essa corporalidade oferece uma plataforma de sentidos para um conjunto de questões que o campo do currículo tem formulado sobre metodologia. O jogo corporal permite-me colocar um sentimento sobre como a pesquisa move-se em uma teia de combinações. Embora reconheça que uma proposta de aquendar a metodologia aparece em Colling (2008), na qual o autor joga com o significado chamar atenção de aquendar, propondo lançar um olhar para analisar a complexidade de produtos culturais que fazem circular representações de homossexuais, é também possível realçar que, tal como o jogar com fitas e esparadrapos, procedimentos e técnicas de pesquisa só existem quando postos em ação.

São, pois, movimentos à medida que fazem corpo e fazem do corpo. As experiências produzidas por atos de corporificação lançam pressões sobre os condicionamentos normativos que os corpos lidam, mas também encorajam variações diferenciais em práticas culturais mais amplas (NOLAND, 2009). Uma engenharia erótica da pesquisa, tomando de empréstimo o termo Denizart (1997) sobre a produção da corporalidade travesti: um jeito de jogar, meio improvisado, para dar um efeito de composição específico e que, portanto, ao mesmo tempo, desloca e transforma a estabilidade dos insumos que mobiliza. Quanto à proposição de uma metodologia queer, sua enunciação remonta, de modo especial, à coletânea organizada por Browne e Nash (2010), intitulada Queer methods and methodologies e ao volume especial Queer studies: methodological approaches da Graduate Journal of Social Science, organizados por Liinason e Kulpa (2008). Entre essas proposições, atravessa uma questão sobre a intersecção dos estudos queers com as formas de fazer pesquisa em Ciências Sociais e afirma-se o potencial de trabalho do queer no seio dos procedimentos e dos compromissos de investigação. Essas incursões interessam-me,

Práxis Educativa, Ponta Grossa, v. 11, n. 2, p. 332-356, maio/ago. 2016 Disponível em: <http://www.revistas2.uepg.br/index.php/praxiseducativa > 
aqui, para problematizar a relação estabelecida com a pesquisa em currículo quando se fala de gênero e de sexualidade. Esta me parece uma condição para que se possa abrir saídas analíticas para o exercício de invenção da vida na educação ou, como escreveu, certa vez, Foucault (2012), sair-se do que se é para criar outros possíveis.

A relevância da metodologia queer não se esgota apenas em descontruir a normatividade nas ciências sociais e humanas - como explora a coletânea de Browne e Nash (2010) - que pesa sobre os modos de fazer pesquisa em currículo, mas também porque, em áreas como a educação, historicamente vinculada à extensão e que apenas mais recentemente vem construindo uma trajetória de produção científica consistente (MACEDO; SOUZA, 2010), os critérios de concessão de inteligibilidade das pesquisas podem contribuir para o sufocamento de suas potências diante deste quadro de consolidação ${ }^{8}$. Uma reviravolta queer constitui em se "[...] interrogar o que o movimento teórico que estabelece fundamentos autoriza e o que precisamente exclui ou priva de direitos [...], encontrar uma maneira de pôr em questão os fundamentos que é obrigado a estabelecer" (BUTLER, 1998, p. 16-18). Minha suspeita é que sentidos do que é e do que faz, do que deve fazer um currículo quanto se trata de gênero e sexualidade, colocam-nos diante de perguntas metodológicas, de como pesquisamos e investigamos esses temas e seus atravessamentos, articulando um quadro de inteligibilidade que rege a pesquisa em currículo, gênero e sexualidade. Quadro este que pode ter seus fundamentos interrogados a fim de abrir outras tramas para a vida de um currículo. Meu ponto é, portanto, que o aquendar - algo como torcer o corpo do pensamento curricular - abre efeitos em termos metodológicos queers.

O que aconteceria se essa torça do corpo propiciasse um estado de suspensão dos modos de pesquisar em currículo no qual resistíssemos à necessidade de explicá-los? Seria possível contestar as normas, as gramáticas e as linguagens nas quais as formas de fazer pesquisa são instituídas? Esta é, de fato, um tipo de defesa associada ao empreendimento queer que, como sugere Valocchi (2005), permite abertura, flexibilidade e mudança quando tratado como metodologia. Porém, apesar de entender que estes possam ser pontos convergentes entre as várias definições de metodologia queer, no que dizem respeito a um modo de fazer pesquisa que se utiliza da crítica queer para questionar e subverter concepções normativas sobre o processo de investigação, é produtivo manter no horizonte a posição de Browne e Nash (2010): mais que estabelecer pontos em comum, a crítica queer leva ao questionamento da própria necessidade de fixar uma concepção única de metodologia. Para a produção de investigações em um campo como o do currículo, no qual a linguagem e o discurso adquiriram relevo, ao mesmo tempo em que se debate contra os fantasmas do positivismo (VEIGA-NETO; MACEDO, 2008), o exercício queer desnatura que uma metodologia qualquer contenha necessariamente uma fórmula clara, precisa e auto-evidente. À esteira de Plummer (2005, p. 173), se “[...] contradição, ambivalência e tensão residem em todas as perguntas críticas", nos movimentos queers não há motivos para resolvê-las; as formas como os compromissos metodológicos tomam permanecem, turvas, contingentes e múltiplas.

Indubitavelmente, como se deve levar a cabo a pesquisa em metodologia queer segue sendo uma pergunta ainda em aberto. Halberstam (1998, p. 35) defende que a metodologia queer é aquela que utiliza "[...] diferentes métodos para coletar e produzir informações [e] rejeita a exigência acadêmica de uma coerência entre as disciplinas". Os estudos queers não se constituem, com efeito, em uma matriz metodológica única. Trata-se de uma variedade de contribuições com

\footnotetext{
${ }^{8}$ Não é, pois, imprescindível deixar de afirmar que as duas últimas décadas da pesquisa em Educação no Brasil, segundo Hostins (2013), caracterizaram-se no Brasil, em especial, por importantes mudanças nos modelos de financiamento, pela demanda da eficiência controlada por meio de sistemas de avaliação e pela demanda por uma formação e por uma produção científica e tecnológica mais focada em necessidades geradas pelas transformações no mundo do trabalho e no setor produtivo.
}

Práxis Educativa, Ponta Grossa, v. 11, n. 2, p. 332-356, maio/ago. 2016 Disponível em: <http://www.revistas2.uepg.br/index.php/praxiseducativa> 
orientações metodológicas distintas, mas que desembocam no esforço de rejeitar a adoção acrítica de qualquer instrumento metodológico, como também de renunciar a adotá-los de forma crítica. Todavia, é conhecido como este desafio à impenetrabilidade das fronteiras disciplinares e o exercício de bricolagem foram postos, desde pelo menos, a entrada dos Estudos Culturais no campo curricular'. Sua agenda política advogou quanto à impossibilidade de exigir, de forma não reflexiva, a adoção de práticas disciplinares e metodológicas cânones da investigação social e antropológica, ainda que nenhuma delas pudesse ser descartada previamente (NELSON; TREICHLER; GROSSBERG, 2008). Apelar para múltiplas leituras, olhares e métodos para compreender práticas culturais, tornou a bricolagem um exercício dos Estudos Culturais a fim de rejeitar diretrizes e roteiros preexistentes e criar processos de investigação reflexivos, estratégicos e pragmáticos à medida que surgem as demandas (KINCHELOE, 2007). Assume-se, neste quadro, que a pesquisa "[...] é uma construção que sofre mudanças e assume novas formas à medida que se acrescentam diferentes instrumentos, métodos e técnicas de representação e interpretação" (DENZIN; LINCOLN, 2006, p. 18). Qualquer investigação é mais um conjunto de imagens mutáveis e interligadas. Uma oscilação e, por certo, uma fragilidade, que deve ser interpretada como um princípio de produção de conhecimento.

Metodologias queers aprenderam com essas experiências dos Estudos Culturais: não têm a pretensão de descompromisso, tampouco de pertencer a todos os lugares; de estar livre, desse modo, dos processos de significação e poder, algo como uma totalidade imaginária, nem mesmo de ser inteiramente autocontida ou inteiramente formalizável. Todavia, retoma-se a bricolagem, agora, de uma maneira radical. Faço referência ao modo como Derrida (2011) tira ilações epistemológicas desse debate ao reler a distinção que Lévi-Strauss (1976) faz entre bricolagem e engenharia. A rigor, suas injunções permitem-me destacar a instabilidade de qualquer itinerário de pesquisa. Nenhum método ou metodologia possui absoluta e intocável unidade. Não existe em uma espécie de estado puro que se possa acessar de forma a caminhar para uma formação metodológica inevitavelmente esperada, sequer pertencem a uma coleção ou repertório de métodos que se pode escolher. Esse campo “[...] é, com efeito, o de um jogo, isto é, de substituições infinitas no fechamento de um conjunto finito [...] ao invés de ser um campo inesgotável [...] em vez de ser demasiado grande, falta-lhe algo, a saber, um centro que detenha e fundamente o jogo das substituições" (DERRIDA, 2011, p. 141). Se sentidos de convenções de pesquisa aparecem, não é, pois, por uma opção deliberada e sempre bem-sucedida de uma reflexão crítica em torno de um repertório constituído de tradições de pesquisa, mas por um jogo de remetimentos de sentidos que os instala discursivamente na proporção que os invoca, sempre que os itinerários da pesquisa implicam seu próprio descolamento.

As práticas metodológicas queers não rompem, desse modo, em definitivo ou praticam qualquer descrédito com as práticas de pesquisas metodológicas conhecidas, muito menos criam ou tem a pretensão de criar algo inteiramente novo. Ao contrário, seus exercícios metodológicos permitem explorar uma espécie de ambivalência que se instaura na pesquisa. Não se trata de transgredir nem de negar as fronteiras dos repertórios e das convenções, na medida em que se reinstauram no processo de investigação, já que somos por eles formados e informados, mas vislumbrar como, no mesmo movimento de reinscrevê-los, os deslocamos e os deformamos invariavelmente. Esse percurso intervalar e, ao mesmo tempo, essa combinação, não permite que uma investigação queer se represente e se faça presente. Isso coloca a metodologia queer no lugar de oscilação do pensamento que previne contra comodidade de convertê-la em um novo modo

\footnotetext{
${ }_{9}^{9}$ Os Estudos Culturais surgem na década de 1960 como prática institucionalizada a partir de pesquisas do Center for Contemporary Cultural Studies sediado na Escola de Birmingham, na Inglaterra. Sua realização mais importante talvez seja a de celebrar o fim de um elitismo edificado sobre as distinções arbitrárias da cultura. Para uma introdução, consultar Matterlat e Nevau (2004).
}

Práxis Educativa, Ponta Grossa, v. 11, n. 2, p. 332-356, maio/ago. 2016 Disponível em: <http://www.revistas2.uepg.br/index.php/praxiseducativa> 
de fazer pesquisa ou em algum tipo de recurso que assente novas bases metodológicas. Cantar diversos modos de queeridade da investigação em currículo não é tentar formular um paradigma diferente de pesquisa educacional. Nessa recusa, reside também uma chance, uma aposta, quem sabe, de converter a pesquisa em currículo em um acompanhamento de traços e pistas incalculáveis da vida em um currículo, que faz abrir outro espaço e tempo que chega a desfigurar o que é "pesquisa".

Talvez, seja, nesse investimento, em que a pesquisa investe na vida fora do lugar e do tempo, que a metodologia queer promova a abertura de sentidos para a pesquisa, pois coloca-nos em atenção para o que sinaliza Gamson (2006): a metodologia queer reascende o caráter produtor e de criação da pesquisa. Aqui, a magia é levada a sério - uma declaração que também ecoa na proposição recente de Cardoso e Paraíso (2013). Entretanto, evita retomar os discursos de genialidade criativa que reinsere a ideia de um sujeito autor fechado em si mesmo, já que a função-autor opera para denotar o estatuto do discurso no interior de práticas culturais (FOUCAULT, 1992). Essa invenção é precária e contingente e, com efeito, não pertence ao pesquisador/a, ainda que se assine com o seu nome. Invenção - do latim invenire -, nota Pringogine (1993), é nada mais do que compor com restos arqueológicos, com pistas, com marcas deixadas em algum lugar. Em jogo, uma concepção limitada de pesquisa como prática produtora de saber, mas que faz dos seus limites suas próprias possibilidades de traçar caminhos. Se for para traçar começos, lança sua partida quando traz à cena uma elucidação sistemática de paradoxos, inconsistências e aporias constitutivas do próprio processo de investigação, aqueles ruídos que têm sido excluídos das pesquisas, relegados às gavetas, ao lixo ou aos arquivos esquecidos nos computadores. Deixa que "[...] o pensamento entregue à intempérie, sem resguardo, oscilante e tremendo diante da estranheza não apropriável do outro" (CRAGNOLINI, 2007 , p. 15) transforma-se em uma questão metodológica. Uma disposição favorável para falar fora do marco de conhecimento que se afirma dominar com segurança, arriscando-se o suficiente para parecer insensata, inclusive, um pouco loka. Torcer seu próprio corpo para inventar outros mundos: aquendar a metodologia.

\section{Das andanças}

As pesquisas em gênero, sexualidade e educação têm desempenhado papel importante em fornecer pontos de referências de como guiar as práticas de investigação em currículo. Um dos procedimentos mais sensíveis - e, portanto, mais elusivos - é trazer para interlocução, docentes e gestores públicos da educação, especialmente quando se trata de sondar sobre a presença de alunos LGBTs (lésbicas, gays, bissexuais, travestis e transexuais) e seus processos de escolarização. Qualquer tentativa de examinar a relação que a educação, a escola ou o currículo estabelecem com o gênero e a sexualidade, entretanto, não tarda em demarcar logo um alheamento, desconhecimento e negação. Como, então, seguir pesquisando sobre currículo e diferença quando gênero e sexualidade são facilmente suscetíveis à encapsulação da educação em um sistema único - científico, moral e político - que oferece uma solução única? O desejo de ampliar as possibilidades de viver o gênero e a sexualidade, que recusa a intransitividade, motiva os exercícios queers a trilhar outros caminhos e experimentar outros itinerários para garimpar espaços de significação diferentes daqueles que vem aprisionando-os em uma concepção cristalizada de currículo. Quando a decantada imagem de pensamento curricular parece suspeita em fazer retornar a mesmidade, uma metodologia queer torna possível perguntar sobre a possibilidade de criar cenários e enredos para esse ofício de tentar deslindar a maquinaria curricular pela qual se cria a vida. Andar entre currículos oferece um desígnio possível para ir tateando, às vezes no simples improviso, caminhos de investigação que só existem como traços e experimentos errantes.

Práxis Educativa, Ponta Grossa, v. 11, n. 2, p. 332-356, maio/ago. 2016 Disponível em: <http://www.revistas2.uepg.br/index.php/praxiseducativa $>$ 
A metodologia queer não prescinde de lançar mão de várias frentes de trabalho e de teias de relações, ao questionar, como faz notar Rooke (2010), as convenções tradicionais sobre o tempo e o espaço de pesquisa, desdobrando-se, no território curricular, em captar sentidos e fluxos culturais que circulam em discursos e materialidades diversas na impossibilidade de blindar os currículos das relações com os tempos e os espaços da sexualidade e do gênero e nos modos como esses sentidos são enunciados. Explorar os meandros curriculares como conexões e combinações complexas de poder suspende aquele sentido de pesquisa que atribui propriedades fixas e estáveis ao currículo, como um espaço e tempo ordenado, marcado pela delimitação e determinação - de uma instituição, de um grupo de sujeitos, de um intervalo temporal. Ali, onde judas perdeu às botas, ali no meio do mundo, e suspeito que em qualquer mundo, há uma gama de práticas que não são visíveis na chave de leitura da política sexual de currículo e parece-me serem essas dimensões que a metodologia queer ajuda a reativar. A incorporação de práticas, de espaços e de tempos outros que não propriamente escolares, como espaços de lazer, de boates, de praças, de organizações não-governamentais, de redes sociais, de aplicativos, de mídias móveis, de músicas, conectados e enunciados sob fragmentos discursivos já deslocados nos espaços e nos tempos curriculares, permite introduzir outros pontos de vistas e sentidos em circulação sobre e nos currículos para além do olhar prescritivo que define o que deve ou não ser ensinado ou da perspectiva de interesse dos poderes que decidem o que é ou não conveniente de ser ensinado em termos de gênero e sexualidade.

É de instaurar um diagrama intensivo de como o movimento de forças de um currículo vai se associando com outros elementos, em uma teia que cria formas de vida e constrói camadas densas e fluentes de relações. Trata-se de experimentar situar a pesquisa em currículo, para se conectar com Halberstam (2005), no tempo e no espaço queer, mas também na torção queer do tempo e do espaço. Essa indicação possibilita a vantagem de evitar aquela dicotomia tão presente no cenário curricular: de um lado, aquele currículo proposto no âmbito formal, dirigido pelas administrações estatais às escolas; e, de outro, aquele vivido e desenvolvido pelas histórias dos "sujeitos" nas escolas. Essa distinção, lembra Macedo (2006), que contribui para uma concepção hierarquizada de poder — seja de dentro-para-fora ou de cima-para-baixo —, dificulta a possibilidade de pensar o currículo para além da prescrição. Essa dificuldade é similar àquela apontada por Butler $(2004,2009)$ de pensar normatividades para além da restrição daquilo que produz. Acompanhar trajetos dos fluxos culturais entre currículos pode indicar um mapa de descolamentos pontuados por contatos significativos das escolas em territórios culturais variados, como o do trabalho, do lazer, das práticas associativas, de produção de comunidades afetivas e redes de suporte que tornam a vida vivível. Territórios que não podem ser vistos como delimitados previamente nem facilmente a partir dos quais se conectariam com as escolas. A tessitura desses territórios é parte de efeitos de relações de força e poder, que tramam elementos heterogêneos em complexidades de alianças no agenciamento curricular. O investimento sobre práticas de "sujeitos" e "grupos" e sobre a paisagem que essas práticas se desenvolvem não é, nessa perspectiva, um simples cenário que influencia a escola. São redes de forças e fluxos culturais constitutivos de subjetivações que se conectam de modo inesperado. Entretanto, a fim de evitar uma pretensa vontade de totalidade, tais espraiamentos permitem antes entender como fluxos de ordens distintas se conectam e se distinguem mutuamente.

Andar entre currículos como quem anda entre diferentes territórios é, portanto, constantemente produzir contrapontos, evitando quaisquer generalizações e abrindo singularidades. Para as perspectivas metodológicas queers em currículo, as diferenças e as mutações, os trânsitos e as transformações dos "novos mapas de gênero e sexualidade" (OLIVEIRA; SANTOS, 2010, p. 97) não se explicam exclusivamente pelas conjunturas e pelos contextos das formações sociais, dos debates ideológicos, dos campos intelectuais sem se levar em conta como funcionam currículos nesses cenários. É que suas maquinarias não podem ser

Práxis Educativa, Ponta Grossa, v. 11, n. 2, p. 332-356, maio/ago. 2016 Disponível em: <http://www.revistas2.uepg.br/index.php/praxiseducativa $>$ 
imunizadas desses cenários de fluídas, irregulares e subjetivas paisagens, sejam étnicas, midiáticas, tecnológicas, financeiras ou ideológicas (APPADURAI, 2001). As andanças queers perguntam-se, assim, em que medida não se está contrastando a leveza e a inventividade dos espaços sociais com a normalização pasteurizada da vida das escolas e se não seria possível proceder um desdobramento da perspectiva que mostre como as entidades e os agentes introduzidos por uma série de mudanças na paisagem da sexualidade tem seu agenciamento nas aplicabilidades políticas e nas capacidades imaginativas dos currículos. Quando vivemos uma ruptura radical nas formas de significar, representar e usar o espaço e o tempo da sexualidade e do gênero e estamos em uma transição entre modos de ser e estar no mundo em que novas subjetividades florescem (HALBERSTAM, 2013), é de se perguntar, nesse sentido, sobre as potencialidades de queerizar a linguagem e a pesquisa em currículo para conhecermos tanto os sentidos da escola quanto para problematizarmos alguns rumos das políticas da diferença em educação.

De fato, as máximas que o mundo mudou tornaram-se lugar comum na literatura pedagógica especializada, ainda que pareça ter mudado muito pouco ou quase nada quando se trata de gênero, de sexualidade e de educação. Essa estagnação no tempo ou mesmo uma obsolescência, que podem ser engajadas naquilo que Ávila (2015) critica como a política cronológica das narrativas desenvolvimentistas - ainda marcantes na educação -, são constitutivas de uma temporalidade, cujas marcas suprimem e devastam modos queers de viver o tempo e o espaço. Como sugere Rizvi (2010), em um mundo em que os fluxos de informação, símbolos e imagens de mídia e ideias políticas e culturais são constantes e implacáveis, novas formações culturais são inevitáveis e transformam as espacialidades - e também as temporalidades - que as pessoas passam a habitar nas escolas. Isso, que tem sido pensado no plano teórico, tem implicações metodológicas, porque, nesse ecúmeno, existem formas de viver o gênero e a sexualidade, em grande parte desconhecidas de uma pesquisa em currículo demasiadamente convencional. Sobretudo, quando a cultura também passa a ser compreendida em termos de movimento e fluxo ${ }^{10}$, os modos metodológicos da pesquisa em currículo para cartografar essas "formulações emergentes da política de gênero" (HALBERSTAM, 2013, p. 7) e da sexualidade na educação também sentem essa necessidade. Nas palavras de Appadurai (1997) para a Antropologia, que bem podem ser válidas para uma perspectiva queer em currículo:

Para dar conta destas temporalidades, [a antropologia] deve se tornar mais flexível, mais ocasional nas suas intervenções, construindo a intimidade espasmodicamente. Porém mesmo estas relações construídas cuidadosamente revelam constantemente os contornos de mais do que [...] pode capturar. [...] hoje em dia, $[\ldots]$ precisa não apenas de um time de outros cientistas sociais, mas também precisa conhecer o que pode tantas disciplinas e literaturas quanto possível $[\ldots]$ provavelmente, sempre foi assim, mas o mundo da globalização não nos deixa outra escolha. (APPADURAI, 1997, p. 118).

Por intermédio de uma multiplicidade de caminhos, um olhar queer para a investigação em currículo favorece um enfoque indisciplinar de pensar a alteridade como um agenciamento da vida dos discursos curriculares em suas articulações com gênero e sexualidade. Para queerizar uma pesquisa em currículo, talvez seja apenas com aquela investigação que suporta, assim, a experiência da privação de segurança, do descentramento e do estranhamento, aquela que insiste nas epistemologias de fronteira (ANZALDUA, 1988), na qual a impossibilidade de delimitar currículo como um território normativo estável, abstrato e universalizado em que a pesquisa se estabelece é provocadora do seu próprio processo. A operação da metodologia queer emerge a partir desses sites intersticiais, cujas fronteiras disciplinares da linguagem curricular não são

\footnotetext{
${ }^{10}$ Nessa perspectiva de cultura, sem pretender ser esgotante e para uma restrição a uma bibliografia recorrente no campo curricular, conferir Hall (1997), Appadurai (2001) e Bhabha (2013).
}

Práxis Educativa, Ponta Grossa, v. 11, n. 2, p. 332-356, maio/ago. 2016 Disponível em: <http://www.revistas2.uepg.br/index.php/praxiseducativa> 
firmemente mantidas. É que a constituição de sentidos de currículo, educação e pedagogia tende a fechar modos de investigação e direcionar o caminho para uma busca de inteligibilidade em detrimento da multiplicidade da pesquisa que tenciona aquele compromisso teórico-político que se advoga como o fundamento da educação. Uma investigação queer acontece nos limites do que é possível pensar, de dizer, de falar e de fazer em pesquisa, enfatizando os processos de normalização e seus escapamentos envolvidos no próprio aprendizado de investigação e o engendramento da vida e do vivível nos currículos.

Afirmar que o poder e o saber estão intimamente relacionados é, certamente, uma contribuição importante, se não saliente, de Michael Foucault ao pensamento queer ${ }^{11}$. É razoável pressupor que o problema do poder desperta as investigações queers a questionar a legitimidade e convenção disciplinar já que o poder produz e atravessa as disciplinas e, por isso, dá-lhes um objeto comum de preocupação. Em evidência, como faz notar Butler (2004), referindo-se à maneira como o conhecimento é produzido a partir de um exterior constitutivo das pesquisas, os limites do conhecimento quando produzido dentro do espectro da disciplinaridade circunscrevem uma esfera de saberes e matizes discursivas subalternizadas. Queerizar a investigação em currículo tem algo a ver com uma disposição que se toma em relação aos sentidos e às imagens de currículo, os quais têm sido protegidos da crítica queer vigente. Em termos queers, as formas de investigação em currículo estão sempre atormentadas por contaminações que não podem ser expurgadas ou geridas facilmente. Metodologia queer torna-se igualmente um inquérito da legitimidade das fronteiras curriculares existentes. Assume que as formas que os currículos tomam em termos de gênero e sexualidade não são cognoscíveis ou previsíveis. Uma queerização da investigação curricular traz à cena um currículo como um espaço e tempo heterogêneos, constituídos de múltiplas, dinâmicas, complexas e heterogêneas relações, não redutíveis a uma dada norma ou forma de poder estagnada. Introduz uma preocupação sobre quais tipos de interpelações de legitimidade sentidos de currículo são mantidos e insiste em um questionamento no interior da própria produção do campo em que participa.

Não se trata, entretanto, de reduzir a metodologia queer a uma série de ensaios sobre as diferentes visões dos mundos ou experiências particulares de um currículo para diferentes sujeitos, de como se processa diversa ou estranhamente em espaços e tempos curriculares. Suspeito que ainda estamos presos em armadilhas de um discurso complacente com a diferença. É sempre bom deixar dito, por um lado, que não há mundo curricular normativo pronto para ser investigado, um mundo antes da divisão entre o visível - o que se pode pensar - e o invisível normas de inteligibilidade que instituem o horizonte de visibilidade. Por outro lado, a recusa em produzir explicações em termos de uma noção transcendental de poder em favor da noção de problematização ou desconstrução, para ficarmos no jargão pós-estrutural, é uma abertura para pensar, algo que Rabinow (2008), em outras paragens, veio a designar de olhar adjacente. Adjacente no sentido de que se mantém em estreita proximidade com o seu "objeto", mas em um intervalo ou ponto de simetria convertido em espaço de problematização. Em outras palavras, há uma relação entre aquilo que é problematizado e o processo de problematização. Essa relação equivale a uma insistência em reconhecer a especificidade da localização espaço-temporal e geopolítica e um apelo à particularidade das questões que coloca. Este trabalho é menos gerador de novas propostas curriculares que gerador de novas perguntas. Trata-se, por fim, de formular com o queer uma alternativa metodológica que seja capaz de apreender potencialidades, multiplicidades e de criar um espaço de suspensão no qual o pensamento curricular não se coadune ao crivo da dedução do que é e do que faz a escola e a educação em termos de gênero e sexualidade.

\footnotetext{
${ }^{11}$ Sobre Foucault e a teoria queer, ver, especialmente, Spargo (2006).
}

Práxis Educativa, Ponta Grossa, v. 11, n. 2, p. 332-356, maio/ago. 2016 Disponível em: <http://www.revistas2.uepg.br/index.php/praxiseducativa $>$ 
Queerizar a investigação em currículo não significa, pois, tomar os "problemas escolares" das pessoas que escapam ao estreito marco heterossexual para propor outra interpretação para o pensamento curricular ou projetar currículos sob inspirações queers. Antes, é realizar uma experimentação com o próprio pensamento curricular. Se essas pessoas são aquelas que colocam as questões de pesquisa em currículo, gênero e sexualidade ou aqueles a quem se endereçam, ao colocarem as questões, antes de tudo, nos questionam, colocam questões curriculares. Para a metodologia queer, os "sujeitos de pesquisa" não são definidos, portanto, por deles partirem os problemas de pesquisa ou, para eles, se endereçarem, nem mesmo a pesquisa se processa "sobre eles". "Sujeitos de pesquisa" abarcam o problema de investigação. É o fato de permitirem dispor problemas e hesitações imaginativas que adquirem relevância. Se aquendar a metodologia leva a explorar excentricidades, está em tanto por serem formas que estão fora do centro e, talvez, dos grandes centros ${ }^{12}$, quanto por serem formas marginais, estranhas, inclusive para a própria pesquisa em currículo. Este empreendimento pretende permitir ao pensamento curricular dizer outra coisa, não sobre corpos sexuados e generificados - pois isso um currículo não poderá deixar de fazer - mas outra coisa sobre si mesmo. Uma metodologia queer não lida, com efeito, com um problema único e dado pela gramática de gênero e sexualidade, mas é a arte de relacionar as dimensões problemáticas postas pelos fluxos culturais contemporâneos nas paisagens da diferença em espaços e tempos curriculares.

Esse é um andar sobre trilhos um pouco bambos já que o propósito deixa de ser o de explicar as normas, expurgá-las ou racionalizar formas de viver e pensar o mundo do gênero e da sexualidade na educação, e passa a ser o de utilizar, tirar consequências, verificar os efeitos que tais formas de vida podem produzir nossos modos de pensar, sentir e diferir em currículo. Aqui, o incômodo reside na invenção perversa de que os modos de vida precisam ser enquadrados, capturados em um código narrativo de universalidade, encouraçados em narrativas constituídas sobre imaginário escolar para ganhar existência política, ao mesmo tempo que é preciso rever a precariedade da vida porque as existências excedem, transbordam, invadem e pulverizam-se nos currículos. Isso quer dizer que o que pensam ou fazem os sujeitos na escola exprimem uma verdade sobre os currículos e suas relações com a escola que se deve levar a sério? Como já ponderava Haraway $(1995$, p. 23 , grifo da autora), “[...] os posicionamentos dos subjugados não estão isentos de uma reavaliação crítica, de decodificação, desconstrução e interpretação; isto é, seja do modo semiológico, seja do modo hermenêutico da avaliação crítica. As perspectivas dos subjugados não são posições 'inocentes". Desse modo, quando explicito "levar a sério", é para colocar entre parênteses a questão de saber se e como as normas curriculares ilustram universais normativos de gênero, explicam certos modos de transmissão social do conhecimento da sexualidade, exprimem uma visão de mundo culturalmente particular, validam a distribuição do poder e outras tantas formas de neutralização da diferença.

Suspender ou evitar encerrar a metodologia queer na pesquisa em currículo nessas questões é decidir pensar a diferença “[...] como vetores sempre a apontar para o outro lado, interfaces transcontextuais cuja função é representar, no sentido diplomático do termo, o outro no seio do mesmo, lá como cá" (CASTRO, 2002, p. 125). A produção da pesquisa queer em currículo não deixa de ser um potente instrumento ficcional, capaz de ampliar e desconstruir os horizontes estéreis da pesquisa em gênero, sexualidade e educação. Ficção, pela filiação ao modo como Butler (2002) a caracteriza: aquele imaginário político que contém todo tipo de maneiras de pensar e escrever que não são necessariamente narrativas ou histórias, mas que são fictícias, no sentido de que delimitam os códigos de inteligibilidade da vida. Quando a produção sobre educação, gênero e sexualidade tem produzido ficções que regulam a inteligibilidade das vidas em

12 Para uma crítica de como a investigação da teoria queer tem se centrado em grandes centros urbanos, conferir Halberstam (2005) e Detamore (2010).

Práxis Educativa, Ponta Grossa, v. 11, n. 2, p. 332-356, maio/ago. 2016 Disponível em: <http://www.revistas2.uepg.br/index.php/praxiseducativa> 
currículo, este trabalho de queerização é uma aventura de ficção porque:

A promessa crítica da fantasia, quando e onde ela existe, é desafiar os limites contingentes do que será ou não designado como realidade. Fantasia é o que permite a nós mesmos e aos outros se imaginar de outro modo; é o que estabelece o possível no excesso do real; a fantasia aponta para outro lugar, e quando o corporifica, converte o familiar neste outro lugar. (BUTLER, 2004, p. 29).

Uma pesquisa que não se debruça "sobre" ou "com" quem quer que seja, mas diante de pessoas "incomuns", "estranhas" e "esquisitas", sobretudo diante daquelas que estão fora de nossa esfera de comunicabilidade na educação. Porém, é de frisar que não se esgota nessa virada. A prática de pesquisa visada pela metodologia queer faz ficção com estranhos materializados como reais para tornar estranhos nós mesmos, nossa própria política, nosso vocabulário, nossa gramática, nosso pensamento curricular.

\section{Das afetações}

Metodologia queer compõe, assim, uma prática de investigação que privilegia a contestação, as conexões e as transformações dos sistemas de conhecimento e as maneiras de ver e dizer dos currículos, uma prática de corpo a corpo, de desejo. Hostil aos relativismos e holismos fáceis, feitos de adição ou subsunção, seus modos de operacionalização podem permitir suspeitar de certa pressuposição de que é preciso escolher, prévia e definitivamente, entre estar dentro ou fora da escola e que, feita tal opção, deixa-se a outra necessariamente de lado. Seria possível colocar rasura na ideia de dentro e fora da escola, ou seja, aceitar essas formulações como possíveis dentro de um quadro que não faz sentido como forma de não fugir ao debate desconstrutivo? Ao seguir aquilo que Gamson (2006) ressalta para como a ênfase dos procedimentos metodológicos queers se coloca sobre os processos de categorização social dos sujeitos e não os sujeitos como tipos sociais coerentes e disponíveis, enfatizam-se como os complexos processos curriculares de materialização dos corpos, não contidos exclusivamente nisto que, vai não vai, tem sido chamado de realidade escolar com um sentido articulado em torno de um chão escolar empiricamente dado. Para esse realismo, que funciona como uma tentativa epistemológica de provar a existência de um mundo real, a metodologia queer não faz muito sentido.

Quando se fala em pesquisa em currículo sem pretensão de generalização, existe uma espécie de recorrência a uma realidade escola a qual se deve pesquisar. Veiga-Neto e Macedo (2008) ponderam que, mesmo a guinada do campo curricular em direção ao discursivo, tem sido tensionada por um realismo que não se consegue abandonar. Ainda que se incorpore o fato de que o real não seja mais pensado como transcendental, não se escapa da ideia de que o conhecimento precisa se referir a um real, ou, pelo menos, a uma de suas dimensões. Essa presença real da realidade, como se existisse dado empiricamente com um fim em si mesmo, tornar-se o terreno de agir, dizer e pesquisar em currículo. Espécie de totalidade genérica que incluiria o conjunto das coisas do mundo, a realidade é convertida em uma espécie de princípio externo e independente, convertida em plenamente real e as coisas em objetos plenamente objetivos (LARROSA, 2008). Todavia, se o real significa o que se encontra presente, o que está realmente aí, plenamente desvelado, qualquer real consiste em um efeito constituído. O que se pode dizer é " $[\ldots]$ mesmo que exista uma realidade para além do nosso entendimento, ela só poderá ser pensada quando estiver sendo (minimamente) entendida e, nesse caso, já não estará mais para além do nosso entendimento" (VEIGA-NETO; LOPES, 2007, p. 5). Isso implica rejeitar não apenas a possibilidade de uma realidade escolar independente dos caminhos pelos quais a pesquisa se faz, bem como a possibilidade de que qualquer coisa pensada, dita e vista

Práxis Educativa, Ponta Grossa, v. 11, n. 2, p. 332-356, maio/ago. 2016 Disponível em: <http://www.revistas2.uepg.br/index.php/praxiseducativa > 
sobre o funcionamento dos currículos contenha representações de uma suposta realidade antes e por fora das normas que se pretende investigar. $O$ que inclui os próprios procedimentos metodológicos, cuja pretensão de tornar transparentes as normas de inteligibilidade é também um marco das relações de poder.

O apelo realista articula uma discursividade cuja estratégia é produzir uma verdade que simule a própria não-simulação de uma realidade escolar. Os discursos do realismo, que invocam uma espécie de autoridade empírica da escola, podem ser escrutinados sobre o que conta como a "realidade", porque esse é também um marco discursivo que delimita de antemão o que será ou não "real". Suspender esse empirismo, no qual mundo real normativo fala por si mesmo, permite reconhecer também as relações de poder que tornam inteligíveis determinados sentidos de currículo em disputa sua própria constituição. Essa realidade que se exterioriza é o terreno sobre o qual se deve agir e dizer algo de modo a garantir a força de um determinado discurso sobre pesquisa em currículo e legitimar a exclusão de outras possibilidades na investigação. A introdução de um tom realista intenta estabilizar a linguagem curricular e, portanto, dificulta a circulação de múltiplos sentidos para outros modos de pensar e fazer pesquisa em currículo. Como argumenta St. Pierre (2008), a presença do realismo é antes efeito dos discursos em meio a relações de poder nas quais se produz a inteligibilidade da pesquisa. Há implicações políticas desse realismo que, inversamente, despolitiza a investigação, já que a intensificação dos artifícios normativos cria ilusões de transparência, desvelando, antes, uma desresponsabilização dos discursos realistas de currículo postos em cena pelas investigações em gênero, sexualidade e educação. É claro que é preocupante o fato de que formas de vida continuem a serem tornadas impossíveis e até mesmo invivivéis, já que não há operação de realidade que não funcione segundo códigos de inteligibilidade. Assim, também é preocupante a ideia de que os sentidos de currículo com os quais operamos, tomados, por sua vez, como "reais", na tentativa de desmontar essas normalizações não promoveriam exclusões e, sobretudo, que suas enunciações são necessárias para o fim de quaisquer exclusões.

Intento apontar que o exercício queer de pesquisa assume a impossibilidade de dar conta das vidas dos sujeitos de pesquisa, bem como falar em nome delas ou por elas. Dito de outro modo, os chamados dados de pesquisa, as descrições, os diários ou qualquer outro registro não são experiências auto-evidentes desta ontologia realista e positivista que domina a pesquisa em educação (ST. PIERRE, 2013) sobre as quais se pode saber ou ter algum tipo de acesso. Scott (1999) alertou sobre o que Spivak (2006) já tinha denominado de autoridade do vivido, apontando que, quando entendida como um evento histórico conectado a significados estabelecidos discursivamente, a experiência é, antes, uma história do sujeito que é tanto coletiva como individual. Os discursos não pertencem a sujeitos isolados, mas seu acontecimento tem uma dívida com uma historicidade condensada (BUTLER, 1997). As palavras, insiste Butler (2009), não expressam plenamente os seres viventes, pois o tempo do discurso recusa a ideia de que o dito se funda no sujeito, dado que estruturas indiferentes que permitem a inteligibilidade da vida pertencem a uma sociedade que tanto constitui quanto excede as subjetividades. $\mathrm{O}$ que chamamos de "dados de pesquisa" não são apenas expressões das normas, mas são tornados possíveis por normalizações que nunca estão dadas previamente. Nesse sentido, St. Pierre (2008) argumenta que essa centralidade não examinada das declarações dos sujeitos na pesquisa e das descrições empiristas funciona como fantasma de um humanismo positivista que recoloca normas de inteligibilidade no processo de pesquisa. Existe, desse modo, uma materialidade de relações que antecedem e excedem quaisquer andanças e combinações, que as constituem, como também as despossuem, em um e no mesmo gesto.

Não é possível produção de conhecimento sem ter em conta as relações estabelecidas com os discursos que nos formam de muitos modos ou que se proponha estar à margem das

Práxis Educativa, Ponta Grossa, v. 11, n. 2, p. 332-356, maio/ago. 2016 Disponível em: <http://www.revistas2.uepg.br/index.php/praxiseducativa> 
forças e das relações de poder e normas que possibilitam a existência da própria investigação. Em outro nível, uma vez assumida essa contingência radical, a metodologia queer abre uma relação não constituída exclusivamente pelo pesquisador/a, nem pelos sujeitos ou objetos de pesquisa, mas que vai conceber a pesquisa como uma rede de relações diferenciais, pela qual esses termos se diferenciam e se relacionam. Há uma das frases famosas de Derrida, destas que até evitamos repetir de tão populares que se tornaram, que bem podem servir a argumentação, "não há nada fora do texto" (DERRIDA, 2010, p. 158). Qualquer investigação começa em meio a múltiplos discursos dos quais quem pesquisa não é autor, e, nesse sentido, não pode ter a esperança de poder saturá-los ou torná-los transparentes. Assim, se no momento em que a investigação passa a existir, o mundo já se encontra estando lá, seria viável pensar modos de investigar que se elevem como um lugar de enunciação. Esse é um lugar indecidível, em que, embora não deixe de reinscrever práticas por meio das quais as regras discursivas sujeitam a investigação, é, ao mesmo tempo, o espaço e o tempo de mostrar como aquilo que nos sujeita habilita o caminhar da investigação. Esse lugar de enunciação é uma cartografia dos desvios, diz Love (2014), que, ao levar em conta as relações altamente específicas, torna-se potente em um momento no qual as vidas queers estão mudando rapidamente, abrindo uma alternativa para os impasses que a crítica queer tem enfrentado quando tenta problematizar as normalizações.

A condição de responder a inteligibilidade normativa é, portanto, mais do que contar uma história sobre o pesquisador, seus interlocutores e suas relações. Quando se fala em metodologia queer, é preciso estudar as condições de produção da pesquisa, ancorando-as nas relações de agenciamento da pesquisa, perguntando-se por formas de inscrições mais atentas às condições políticas que inserem as possibilidades de pesquisa. É possível sublinhar isto a partir de uma reflexão de Canclini (1991, p. 62), "[...] para saber como conhecer melhor é necessário conhecer melhor como nos organizamos para conhecer: como se interiorizam em nós hábitos metodológicos e estilos de investigação que consagram as instituições e os dispositivos de reconhecimento". Contudo, quando nos calibramos diante dessas pistas, já estamos implicados em uma temporalidade social que excede as capacidades descritivas de qualquer investigador/a. Esse atravessamento "[...] recusa a ideia de que o dito se funda somente em mim, dado que as estruturas indiferentes que permitem o meu viver pertencem a uma sociedade que me excede" (BUTLER, 2009, p. 55). Quando um sujeito procura dar conta da pesquisa sem deixar de incluir, mesmo que escape sua própria possibilidade, as condições de sua emergência, "[...] tem que se converter, por força, em teórico social” (BUTLER, 2009, p. 19). Esse lugar é menos um conjunto de ideias que pretendem fazer justiça a quem quer seja. É antes um operador que busca transformar a massa escapável da vida de um currículo em uma verdade com objetos suportáveis e sujeitos nomeáveis. Aqui, retornarmos a um terreno que é muito pouco queer. É que o terreno queer não é um lugar pronto, uma reserva para qualquer obra normativa, precisando, ao contrário, tudo repensar a cada interpelação de vida.

É mesmo possível pesquisar em um lugar incerto, dos que não tomam o real como um tema ou um objeto, mas como uma intensidade? Quero sugerir, pois, que as relações com os outros - os "sujeitos de pesquisa" - tomam formas que nem sempre se pode explicar ou contar formas que a princípio interrompem os relatos autoconscientes da normalização operante na escola e que desafiam a versão de que qualquer um de nós seja um sujeito autônomo capaz de controlá-lo. Essa relação não leva, contudo, ao silêncio ou à impossibilidade de traçar uma investigação, mas sutura o discurso da pesquisa com signos em decomposição quando se entra em uma relação na qual o correlato tende a evadir-se dela. Esse caminhar por meio de pistas torna-se uma máquina de ficções acerca das relações normativas que nos produzem somente para mostrar em algum lugar da trajetória o modo como essas mesmas relações se apoderam e desintegram qualquer pretensão de unidade. A força e a tensão do caminho residem no modo como nos encontramos continuamente alcançando algo que, não obstante, retira-se da esfera do

Práxis Educativa, Ponta Grossa, v. 11, n. 2, p. 332-356, maio/ago. 2016 Disponível em: <http://www.revistas2.uepg.br/index.php/praxiseducativa $>$ 
alcance, resistindo a ser subsumido pelo horizonte de pensamento. Pesquisa torna-se, assim, o nome que se pode dar a forma pela qual tentamos, ou somos convocados inevitavelmente, ainda que de modo vacilante, a dotar de inteligibilidade as teias de relações de poder e de forças que nos escapam. É também o nome de como a vida está profundamente relacionada ao movimento e à agência de outros mundos nos currículos que nos confrontam em uma existência - existência que nem sequer depende da pesquisa ratificar ou assumir.

Não há imposição, portanto, metodológica, porque quaisquer que sejam os movimentos tomados advêm dos encontros com os sujeitos de pesquisa, com espaços, os tempos, os objetos, as ideias que circulam. Como se pergunta Caputo (2002, p. 39), "[...] existe forma melhor de superar a alucinação, por um lado, e de superar o realismo reificante, por outro lado, do que prestar atenção ao outro que vem bater na minha porta?”. Em outras palavras, investigação queer faz um movimento metodológico como um modo de responder a interpelação da alteridade. Quando escrevo sobre esse encontro, refiro-me a algo que causa uma impressão, algo que suspende os horizontes de expectativa e que nos põe diante do que não somos, permanecendo o tempo todo fora da esfera de apreensão. Concordo com Favret-Saada (1980), para quem a vivência do "trabalho de campo" é tão mais produtiva quanto o pesquisador se permita ao que chamou de "ser afetado". Esse estado não tem nada a ver com uma operação de conhecimento por empatia, qualquer que seja seu sentido. Ser afetado, advoga Favret-Saada (1980), é como uma modalidade de experimentação de intensidades específicas, somente possível a partir da interpelação de relações de força sem a qual não se teria acesso a elas e que abrem uma comunicação específica que não é passível de representação. Permitir-se ser afetado pode indicar caminhos de pesquisa para além do quadro de reificação das normas nos currículos, para além das malhas de um poder em que tudo é controle por parte da pedagogia, da educação, dos docentes, da escola. Quando Sedgwick (2003) se interessou em usar o afeto, pretendia desafiar o que chama de hermenêutica paranoica cujo funcionamento ancora o imaginário da teoria queer, reduzindo-se à busca e ao contínuo amortecimento dessa redescoberta, da proibição em todos os lugares.

Por mais precários que sejam essas afetações - essa expressão que, vai não vai, usa-se para descrever muito dos jeitos corporais dos meninos com quem estive - há a possibilidade de se insinuarem afetos. Trata-se, entretanto, de pensar as afetações como parte de um processo de pesquisa para além de enfatizar uma dimensão existencial da experiência do pesquisador. Afetos podem ser tomados como "[...] forças corpóreas pré-individuais que aumentam ou diminuem a capacidade do corpo em agir" (CLOUGH, 2010, p. 207), portanto, mais em sintonia com as configurações de uma subjetividade e processos sociais e discursivos que desconstroem a centralidade da condição humanista tão privilegiada pela pesquisa educacional. Mesmo que a afetação implique abrir o corpo da pesquisa e os corpos na pesquisa, é fundamental uma dimensão histórica e cultural das relações que afetam a pesquisa. À esteira do que propõe Massumi (1998), as afetações são relações sociais em uma forma anterior à separação dos indivíduos e há uma memória corpórea constituída por uma temporalidade não linear. Nessa direção, as relações de pesquisa denotam um componente afetivo, tomando de empréstimo o conceito de "efêmero" de Muñoz (2009, p. 65), “[...] como traço, restos, coisas que são deixadas, penduradas no ar como um rumor". O afeto sugere como uma investigação produz modo camadas de reações que escapam a explicações e deslocam nossa maneira de ver e viver currículos, porque formas de vida com as quais nos relacionamos "muitas vezes deixam vestígios efêmeros e incomuns" (CVETKOVICH, 2003, p. 8). Este empreendimento do afeto está ligado a uma abordagem de currículo como tendo uma vida inesperada, gerando um modo de pesquisa que desafia a narrativa de um projeto curricular de uma sociedade sem poder, dominada pelo orgulho de ser, pois esses sentidos tornam difícil abordar currículo como algo vivo, dissonante, além do controle e capaz de tocar a vida.

Práxis Educativa, Ponta Grossa, v. 11, n. 2, p. 332-356, maio/ago. 2016 Disponível em: <http://www.revistas2.uepg.br/index.php/praxiseducativa> 
O produtivo deste ato de ser afetado é fazer borrar, como nota Jackman (2010), a linha divisória que insiste na separação entre aquele que pesquisa e aqueles/as que foram pesquisados. Como defende Reis (2012), pesquisadores e pesquisados são coprodutores sobre os atos e os corpos observados. Se afetar-se está relacionado às redes de relações que dotam os corpos de existência e neles se inscrevem, seria razoável admitir que o movimento da diferença, que tanto ultrapassa como inscreve os caminhos metodológicos, abre possibilidades para algumas práticas desestabilizadoras de modos de produzir pesquisa, inclusive para um senso de criação e invenção independente dos mundos das ciências. Pode ser potente defender que não estamos no comando da pesquisa, que nós, pesquisadores, não somos os únicos a fabricar discursos ou a inventar ficções com as quais lidamos e pelas quais somos atravessados e constituídos. Isso não quer dizer, com efeito, que pesquisadores e interlocutores da pesquisa participam do mesmo modo, pois os modos com que nos implicamos são diferentes e operam diferencialmente. Strathern (1987) chama a atenção para o modo como os diferentes sujeitos interpelados em uma pesquisa são colocados em diferencial relação com as técnicas de conhecimento/teorização, não permitindo afirmar que as relações com os discursos sejam, portanto, as mesmas. Todavia, a metodologia queer impede que conceitos como "sujeito" e "objeto", "pesquisador" e "sujeito de pesquisa" se apresentem sob uma lei perpetuamente dual. Esse quadro permite atentar para os limites da produção de investigações bem como sobre a necessidade de abertura da pesquisa em currículo a formas de dizer, falar e pensar a vida não colonizáveis por sentidos hegemonizados da linguagem curricular.

Não se trata, certamente, da transformação no outro que atravessa e se interpõe na pesquisa, porque o que está em jogo na afetação é situar-se e ser situado em uma rede de relações nas quais se pode ser afetado pelas mesmas forças que incidem sobre os outros. Logo, permitir-se a este toque não informa sobre o afeto do outro, mas sobre o que afeta as relações de pesquisa no espaço e no tempo em que múltiplos discursos o colocam. É fundamental reconhecer que, em relação aos estudos sobre gênero e sexualidade, tem sido frequente cruzar os limites do conhecimento. "Nesse jogo, "sua" (aspas são para marcar um campo de desconfiança com a noção de propriedade que temos do eu) própria subjetividade, corpo, sexualidade, gêneros e projetos de vida se veem na berlinda (BENTO, 2011, p. 85). Pode-se questionar até que ponto esse afetar incidiria sobre o pensamento curricular e como permitem interrogá-lo, mas é que não podemos entender as afetações à margem de uma concepção de relações corporais de pesquisa. O corpo de quem pesquisa e aquilo que o afeto faz é, de fato, um aparato metodológico que produz parte daquilo que se investiga, na medida em que também participa da experiência da pesquisa. Quando se trata de uma aventura metodológica queer há de se problematizar os limites do corpo de quem pesquisa para poder trazer à tona como o ato discursivo afeta e anima de um modo corporal, como este campo de suscetibilidade e afetação da pesquisa é uma questão de registro corporal.

Os corpos "dos pesquisadores" apenas vivem na pesquisa, atravessados por múltiplas relações contingenciais de afeto que inscrevem a inteligibilidade daquilo que investigam, ao passo que investigam a própria materialidade dessas inervações. Tentam estabelecer, nesse movimento, conversas complicadas, nos termos já clássicos de Pinar (2004), não inocentes, carregadas de poder, por meio de próteses, para usar outro termo largamente divulgado na teoria queer por Preciado (2002), incluídas aí técnicas e as convenções metodológicas que se veem, de um modo ou de outro, distorcendo. Talvez, o que a metodologia queer faça na pesquisa em currículo é uma relação de sentido com outros discursos diante daqueles tratados como outros da educação, ou para já dizer de outro modo, um exercício de outramento dos nossas discursividades. Inscreve-se a si mesma como uma relação entre uma série de outras relações, de algum modo, eclipsadas nas posições de "pesquisador" e "sujeitos de pesquisa". Porém, em se tratando de relação, não há possibilidade de que seus termos não se transformem. Em outras palavras, essas duas posições

Práxis Educativa, Ponta Grossa, v. 11, n. 2, p. 332-356, maio/ago. 2016 Disponível em: <http://www.revistas2.uepg.br/index.php/praxiseducativa> 
comumente envolvidas na pesquisa - ainda que os caminhos não possam ser nelas esgotadas contêm um potencial de transformação, pelo qual a diferença prolifera, decompõe e faz o caminho de pesquisa oscilar.

\section{Das fecundações}

Herdeiros de uma ontologia dualista, estaríamos carentes de uma metodologia de investigação em currículo apta a recuperar o crédito que a vida tecida das pessoas diante das quais traçamos os caminhos de investigação deveriam ter. Não sei se a metodologia queer pode ser uma resposta - nem mesmo se pode funcionar como tal -, mas quando chegou aquele momento em que, ao ser interpelado sobre como se faz a pesquisa, pareceu-me que era preciso tomar uma saída que proliferasse a vida da diferença em um currículo. Trata-se de tomar distâncias das convenções metodológicas de que dispomos para pensar mediante pontos de vistas descentrados e que possam, por sua vez, torcer os instrumentos metodológicos, fazendo de tais conexões insuspeitas, modos de condução de pesquisa. Seus movimentos produzem interfaces para ecoar estranhamente aquele outro lado do pensamento curricular, ou seja, tudo aquilo que se vê como seu lado menor, marginal, excêntrico: o lado daqueles que fracassam, na expressão de Halberstam (2011), diante da história intelectual da educação. A promessa de pensar mediante a analítica da normalização (MISKOLCI, 2009) e à política da abjeção (BENTO; PELÚCIO, 2012), às coisas estranhas mesmas, não implica oferecer teorias consumadas sobre o agenciamento da vida nos currículos. Talvez seja por essa razão, que não haja um movimento homogêneo no que concerne às ressonâncias que figuraram este aquendar a metodologia. $\mathrm{O}$ programa de pensar mediante aos estranhos, aos abjetos, aos excêntricos, nos desobriga, portanto, da filiação a boticários e alienistas.

O compartilhamento de esferas de intimidade cultural e de experiências de múltiplas margens proporciona, assim, o acesso não a alguma verdade oculta, mas a outras relações de sentido que não emergem diretamente nos discursos estandardizados sobre currículo. Se não "tirarmos proveito" desta situação, estamos limitados a atualizar o discurso usado para obter reconhecimento de formas de vida em distintas instâncias. Esse cenário pode também permitir que, no momento da elaboração da descrição, o efeito da presença e da corporalidade possa ser tornado visível pela experiência de relacionamento. Não porque altere ou promova efeitos disruptivos no fluxo "normal" da vida - Strathern (1999) já havia sugerido que as relações sociais estabelecidas em campo devem ser valorizadas em si mesmas, pois delas derivam o conhecimento que se produz -, mas pelos sentidos que parecem evocar sobre currículo de modo a regular a própria possibilidade de investigação. Também pode proporcionar a expansão do sentido da invenção na pesquisa por meio da abertura do nosso pensamento para a criatividade do discurso dos outros. A invenção - tão central ao argumento desenvolvido por muitas das perspectivas pósestruturais quando dizem da metodologia de pesquisa -, não se contrapõe nem a uma "realidade" nem é construída como uma propriedade exclusiva de um sujeito humano. Apresenta-se como um modo relacional mediante o qual discursos são transformados no ato mesmo em que são agenciados em contextos transversais de investigação, para que carreguem tanto as localizações como diferentes estranhamentos no interior da própria investigação.

Essa fecundação é, portanto, produtiva pela divergência que suscita no pensamento curricular. Uma sugestão de Goldman (1999), a partir de uma ideia de Guimarães Rosa, pode iluminar um caminho possível. No prefácio de uma obra húngara traduzida, Guimarães Rosa faz referência à inevitável traição da língua traduzida no processo de tradução. A proposta do escritor é, sobretudo, ética: o tradutor deve-se permitir uma fecundante corrup̧̧ão, isto é, contaminar o seu próprio idioma, corrompê-lo por meio da língua que deveria ser traduzida. Trata-se, pois, de uma

Práxis Educativa, Ponta Grossa, v. 11, n. 2, p. 332-356, maio/ago. 2016 Disponível em: <http://www.revistas2.uepg.br/index.php/praxiseducativa $>$ 
ética - e por que não um método? - de tradução. A enriquecedora "corrupção" da linguagem de currículo pelas formas de vida que se pesquisa constitui um modo de fazer o discurso "dos outros" fecundar no interior dos discursos curriculares, potencializando como prática de sentido. Ao invés do exercício de controle ou abarcamento normativo, permite-se experimentar, multiplicar, expandir sentidos na descrição dos mundos que produzimos, por meio da proliferação da criatividade dos modos vida com quem entramos em relação. $O$ trabalho da metodologia queer é tanto mais complexo quanto mais experimentamos o esforço de ultrapassar essas declarações para efetuá-las. No fim das contas, é, da mesma situação de seu "objeto", estranha. Um compromisso ético-político que intenta questionar seus próprios fundamentos, arriscando-se a tornar-se impura graças às trocas e às traduções com outros corpos, outras perspectivas, outras vidas.

Um exercício que, quiçá, permite aos corpos marginais não necessitarem dirigir suas estratégias de oposição para um horizonte curricular que é concebido como horizontal; que nos habilita a compreender que olhares de outros modos, avessos e estranhos são construídos desde dentro, ali nas zonas de impurezas e incertezas da maquinaria curricular. Aquendar a metodologia: levar a sério a possibilidade de os currículos serem afetados em situações de alteridade radical, pois um enfoque exclusivo nos processos de reificação normalizadora acaba por impedir uma aproximação com a complexidade da própria experiência de gênero e de sexualidade na educação. Queerizar a investigação em currículo significa aventar a probabilidade de formas criativas de corporalidade e da vida afetarem o pensamento curricular. Admitir que a experiência com alteridade radical nada provoca no pensamento curricular seria atribuir um poder desmesurável à normalização, além de uma homogeneidade à vida e, sobretudo, uma extrema debilidade àqueles que escapam ao estreito marco heterossexual. Emerge uma necessidade de se afastar de uma postura que esteriliza a multiplicidade da vida dos currículos e desenha suas estratégias como exercícios de controle, privilegiando apenas a vinculação com os discursos científicos e morais, considerados também como homogêneos, ignorando-se a complexidade e a historicidade do modo como as vidas e os corpos se tecem nos currículos. Queerizar é a tentativa errante de colher pistas efêmeras da vida em direção a tornar estranhas as relações de captura e assujeitamento das pessoas como esgotantes dos currículos, perguntando-se como também mostram - ou praticam montagens - disjunções, hesitações, lapsos e movimentos.

\section{Caminhar nas pistas do limite}

Todo esse movimento que fiz me ajuda, agora, a retomar o caminhar da investigação como gestos explícitos de montagem, afetação, combinação e fecundação. Suspeito que há algo não percebido no mundo da educação. Mesmo as conversas entreouvidas e olhares entrecortados que não mudam a direção das projeções normativas curriculares, carregam em possibilidades e ruídos da vida. Na maquinaria pela qual a escola constitui a vida, nada diz que ela tenha se esvaído. Queerizar a investigação em currículo permite explorar como as formas de viver a sexualidade e o gênero reverberam, rearticulam e deslocam discursos e significados e afetam, de tal modo, à esteira do que propõe Ochoa (2004), a formação de nossos projetos políticos para a educação, nosso imaginário político do que é e do que faz um currículo. Uma abordagem, que apenas caracterize currículos como meros implementadores da reificação normativa, desconsidera as fissuras das experiências de gênero e sexualidade no pensamento curricular. Indicação pertinente para sugerir que uma investigação queer em currículo devolve sentidos e imagens de currículo em que não nos reconhecemos, oferece uma oportunidade para realizar uma experimentação sobre nossa imaginação curricular. Na observação de Cornell (1995, p. 8), “[...] nosso sentido de liberdade está intimamente ligado à renovação da imaginação, na medida em que nos reconciliamos com o que somos e com o que desejamos ser como seres sexuados". Para um

Práxis Educativa, Ponta Grossa, v. 11, n. 2, p. 332-356, maio/ago. 2016 Disponível em: <http://www.revistas2.uepg.br/index.php/praxiseducativa> 
olhar queer de pesquisa, é potente empreender uma problematização sobre os limites dos campos de inteligibilidade e sobre como os jogos estéticos, corporais e imaginativos permitem realizar campos imaginados no pensamento e na política curricular. Imaginar ${ }^{13}$ não é, nesse caso, o contrário de investigar, é abrir a investigação para o que até agora permanece impensável.

Em um momento em que este texto ameaça se decompor, questões não resolvidas retornam, revelam-se elementos soterrados, trazendo à luz aspectos não resolvidos nos modos de caminhar em uma investigação. Qual a produtividade dos apontamentos de uma perspectiva queer para os sentidos de pesquisa em currículo? Quais os limites e as potências desses deslizamentos para a investigação em educação? Como lidar com as tensões geradas no processo de significação do queer no bojo da metodologia de pesquisa? É possível pesquisar o impensável do pensamento curricular? Essas notas mostram o quanto um estranhamento queer buscaria lançar um corpo a corpo de pesquisa, nos quais "sujeitos de pesquisa", "pesquisador" e "pesquisados", são formados e forjados, mas também para que o currículo não seja formatado e valorado a partir de discursos hegemônicos que, em última instância, reificam seu lugar de normalização totalitária e controle inescapável. Como Puar (2005, p. 121) argumentou "[...] tempos queers requerem mesmo queerizar modalidades de pensamento, análise, criatividade e expressão". Essa queerização da investigação em currículo investe na política de diferença, nas fraturas dos espaços e dos tempos dos discursos curriculares que, se não permitem fazer qualquer coisa com os corpos, também não deixam de estarem sujeitos ao escapamento. Por fim, pergunta-se: onde estão a inquietação, a contaminação, a ambivalência, que sempre se creditou serem o mote das perspectivas queers quando se diz e se faz pesquisa em currículo, gênero e sexualidade? Aquendar a investigação em currículo: uma montagem que picota a vida em dias quaisquer, para que o óbvio, o comum, o inexpressivo se torne excêntrico, fora do centro e fora de lugar. Drag-queens da pesquisa mesmo sem maquiagem no rosto e com um bloco de notas na mão.

\section{Referências}

ANZALDUA, G. Borderlands/ La frontera. São Francisco: Aunt Lost Books, 1988.

APPADURAI, A. Discussion: fieldwork in the era of globalization. Antropology and humanism [online], v. 22, n. 1, p. 115-118, 1997. DOI: 10.1525/ahu.1997.22.1.115

APPADURAI, A. La modernidad desbordada. Buenos Aires: FCE, 2001.

ASSIS, J. M. M. de. O Alienista. São Paulo: Ática, 1992.

AVILA, E. Do high-tech à azteca: descolonização cronoqueer na ciberarte chicana. Revista de Estudos Feministas, Florianópolis, v. 23, n. 1, p. 191-206, jan./abr. 2015. DOI: 10.1590/0104026X2015v23n1p191.

BENTO, B. Política da diferença: feminismos e transexualidades. In: COLLING, L.; THURLER, D. (Orgs.). Stonewall 40+ o quê? Salvador: UFBA, 2011. p. 79-110.

BENTO, B.; PELÚCIO, L. Despatologização do gênero: a politização das identidades abjetas. Revista Estudos Feministas, Florianópolis, v. 20, n. 2, p. 123-155, maio/ago. 2012. DOI: http://dx.doi.org/10.1590/S0104-026X2012000200017

BHABHA, H. O local da cultura. Belo Horizonte: UFMG, 2013. 13 Para desdobramentos de sobre o lugar da imaginação no campo político e cultural, conferir Nandy (2015),
Appadurai (2001) e Rizvi e Lingard (2010).

Práxis Educativa, Ponta Grossa, v. 11, n. 2, p. 332-356, maio/ago. 2016 Disponível em: <http://www.revistas2.uepg.br/index.php/praxiseducativa> 
BOELLSTORFF, T. Queer Techne: Two theses on methodology and queer studies. In: BROWN, K.; NASH, C. (Orgs.). Queer methods and methodologies. London: Asghate, 2010. p. 215230.

BROWNE, K.; NASH, C. (Orgs.). Queer methods and methodologies. London: Asghate, 2010.

BROWNE, K.; NASH, C. Introduction. In: BROWNE, K.; NASH, C. (Orgs.). Queer methods and methodologies. London: Asghate, 2010. p. 1-24.

BUTLER, J. Fundamentos contingentes: feminismo e a questão do pós-modernismo. Cadernos Pagu, Campinas, n. 11, p. 11-42, 1998.

BUTLER, J. Excitable speech. Nova York: Routledge, 1997.

BUTLER, J. Como os corpos se tornam matéria: entrevista com Baukje Prins e Irene Costera Meijer. Revista de Estudos Feministas, Florianópolis, v. 10. n. 1, p. 155-167, $1^{\circ}$ sem. 2002. DOI: 10.1590/S0104-026X2002000100009

BUTLER, J. Undoing Gender. New York/London: Routledge, 2004.

BUTLER, J. Cuerpos que importan. Buenos Aires: Paidós, 2008.

BUTLER, J. Dar cuenta de sí mesmo. Buenos Aires: Amorrortu, 2009.

BUTLER, J. There are some muffins there if you want... a conversation on queerness, Precariousness, Binationalism, and BDS. In: ALONI, U. (Org.). What does a Jew want? New York: Columbia University Press, 2011. p. 204-227.

CANCLINI, N. G. Construcción o simulacro del objeto de estudio? Trabajo de campo y retórica textual. Alteridades, Colonia Vicentina, México, n. 1, p. 58-64, 1991.

CAPUTO, J. Por amor às coisas mesmas: o hiper-realismo de Jacques Derrida. In: DUQUEESTRADA, P. C. Às margens. Rio de Janeiro: PUC Rio, 2002. p. 29-48.

CARDOSO, L. R.; PARAÍSO, M. A. Possibilidades de uma metodologia alquimista para pesquisar em educação e em currículo. Revista e-Curriculum, São Paulo, v. 11, p. 270-290, abr. 2013.

CASTRO, E. V. de. O nativo relativo. Mana, Rio de Janeiro, v. 8, n. 1, p. 113-148, 2002. DOI: 0.1590/S0104-93132002000100005

CLIFFORD, J. Routes. Cambridge: Harvard University Press, 1997.

CLOUGH, P. The affective turn. In: GREGG, M.; SEIGWORTH, G. (Orgs.). The affect theory reader. Durham: Duke University Press, 2010. p. 206-225.

COLEBROOK, C. On very possibility of queer theory. In: NIGIANNI, C.; STORR, M. (Eds.). Deleuze and queer theory. Edinburgh: Edinburgh University Press, 2009. p. 11-23.

COLLING, L. Aquenda a metodologia! - uma proposta a partir de avental todo sujo de ovo. Bagoas: revista de estudos gays e lésbicos, Natal, n. 2, p. 153-170, 2008.

CORNELL, D. The imaginary domain. Nova York: Routledge, 1995. 
COSTA, M. V. Caminhos investigativos: novos olhares na pesquisa em educação. Rio de Janeiro: DP\&A, 2002a.

COSTA, M. V. Caminhos Investigativos II: outros modos de pensar e fazer pesquisa em educação. Rio de Janeiro: DP\&A, 2002b.

COSTA, M. V.; BUJES, M. I. E. (Orgs.). Caminhos Investigativos III: riscos e possibilidades de pesquisar nas fronteiras. Rio de Janeiro: DP\&A, 2005.

CRAGNOLINI, M. Temblores del pensar: Nietzsche, Blanchot, Derrida. Pensamiento de los Confines, Buenos Aires, n. 12, p. 11-19, 2007.

CVETKOVICH, A. An archive of feelings: Trauma, sexuality and public cultures. Durham and London: Duke University Press, 2003.

DENIZART, H. Engenharia erótica. Rio de Janeiro: Jorge Zahar, 1997.

DENZIN, N. K.; LINCOLN, Y. S. Introdução: a disciplina e a prática da pesquisa qualitativa. In: DENZIN, N. K.; LINCOLN, Y. S. (Orgs.). O Planejamento da pesquisa qualitativa: teorias e abordagens. Porto Alegre: Artmed, 2006. p. 15-42.

DERRIDA, J. A escritura e a diferença. São Paulo: Perspectiva, 2011.

DERRIDA, J. Gramatologia. São Paulo: Perspectiva. 2010.

DETAMORE, M. Queer Appalachia: Toward Geographies of Possibility. 2010. 227 f. Tese. (Doutorado em Antropologia) - University of Kentucky, Lexington, EUA, 2010.

DOEL, M. Corpos sem órgãos: esquizoanálise e desconstrução. In: SILVA, T. T. (Org.). Nunca fomos humanos: nos rastros do sujeito. Belo Horizonte: Autêntica, 2001. p. 77-110.

FAVRET-SAADA, J. Être affecté. Gradhiva, Paris, n. 8, p. 3-10, 1980.

FOUCAULT, M. História da sexualidade II: a vontade de poder. Rio de Janeiro: Graal, 2012.

FOUCAULT, M. O que é um autor? Lisboa: Vega, 1992.

GAMSON, J. As sexualidades, a teoria queer e a pesquisa qualitativa. In: DENZIN, N. K.; LINCOLN, Y. (Orgs.). O planejamento da pesquisa qualitativa. Porto Alegre: Artmed, 2006. p. 345-362.

GOLDMAN, M. Alguma antropologia. Rio de Janeiro: Relume-dumará, 1999.

HABER, A. Nometodología Payanesa: Notas de metodología indisciplinada. Revista Chilena de Antropología, Santiago, n. 23, p. 9-49, ago. 2011. DOI: 10.5354/0719-1472.2011.15564

HALBERSTAM, J. Female masculinity. Durham: Duke University Press, 1998.

HALBERSTAM, J. In a queer time and place. New York: New York UP, 2005.

HALBERSTAM, J. The queer art of failure. Durham: Duke University Press, 2011.

HALBERSTAM, J. Gaga feminism. Boston: Bacon Press, 2013.

HALL, S. A centralidade da cultura: notas sobre as revoluções culturais do nosso tempo.

Educação \& Realidade, Porto Alegre, v. 22, n. 2, p. 15-46, jul./dez. 1997. 
HARAWAY, D. Saberes localizados. Cadernos Pagu, Campinas, n. 5, p. 7-41, 1995.

HOSTINS, R. C. L. Formação de pesquisadores em programas de excelência de pós-graduação em Educação. Revista Brasileira de Educação, Rio de Janeiro, v. 18, n. 53, p. 415-498, abr./jun. 2013. DOI: $10.1590 /$ S1413-24782013000200010

JACKMAN, M. C. The trouble with fieldwork: queering methodologies. In: BROWNE, K.; NASH, C. (Orgs). Queer methods and methodologies. London: Asghate, 2010. p. 113-128.

JAGOSE, A. Queer theory: an introduction. New York: New York University Press, 1996.

KINCHELOE, J. L. Redefinindo e interpretando o objeto de estudo. In: KINCHELOE, J. L.; BERRY, K. S. (Orgs.). Pesquisa em educação. Porto Alegre: Artmed, 2007. p. 101-122.

LA FOUNTAIN-STOKES, L. Translocas: migração, homossexualidade e transformismo na recente performance porto-riquenha. E-hemisférica, Nova Iorque, v. 8, n. 1, 2011.

LARROSA, J. Pedagogia profana: danças, piruetas e mascaradas. Belo Horizonte: Autêntica, 2008.

LÉVI-STRAUSS, C. O pensamento selvagem. São Paulo: Nacional, 1976.

LIINASON, M.; KULPA, R. Queer studies: methodological approaches. Graduate Journal of Social Science [online], n. 5, v. 2, p. 1-4, 2008.

LOVE, $\mathrm{H}$. The natural history of queer: affect, impersonality, and the social science roots of sexuality studies. Palestra conferida na Univesity Library, Amsterdam, 2014. (mimeo).

MACEDO, E. Currículo: cultura, política e poder. Currículo sem Fronteiras [online], v. 6, n. 2, p. 98-113, 2006.

MACEDO, E. The internationalization of curriculum studies. AAACS Annual Meeting, Nova York: AAACS Annual Meeting Proceedings, 2008. p. 1-10.

MACEDO, E.; SOUZA, C. A pesquisa em educação no Brasil. Revista Brasileira de Educação, Rio de Janeiro, v. 15, n. 43, p. 166-202, jan./abr. 2010. DOI: 10.1590/S141324782010000100012

MASSUMI, B. Requiem for our prospective dead: toward a participatory critique of capitalist power. In: KAUFMAN, E.; HELLER, K. J. Deleuze and Guattari. Minneapolis: University of Minnesota Press, 1998. p. 40-64.

MATTELART, A.; NEVEU, E. Introdução aos estudos culturais. São Paulo: Parábola, 2004.

MEYER, D.; PARAÍSO, M. (Orgs.). Metodologias de pesquisas pós-críticas em educação. Belo Horizonte: Mazz Edições, 2012.

MILLER, J. L. Poststructuralism research. In: KRIEDEL, C. (Org.). Encyclopedia of curriculum studies. Los Angeles, CA: SAGE, 2010. p. 676-680, v. 2.

MISKOLCI, R. A teoria queer e a sociologia: o desafio de uma analítica da normalização. Sociologias, Porto Alegre, v. 11, n. 21, p. 150-182, jan./jun. 2009. DOI: 10.1590/S151745222009000100008

MUÑOZ, J. E. Cruising utopia. New York: New York University Press, 2009. 
No meio do mundo, aquendar a metodologia: notas para queerizar a pesquisa em currículo

NANDY, A. A imaginação emancipatória. Belo Horizonte: UFMG, 2015.

NELSON, C.; TREICHLER, P. A.; GROSSBERG, L. Estudos Culturais: uma introdução. In: SILVA, T. T. (Org.). Alienígenas na Sala de Aula. Rio de Janeiro: Vozes, 2008. p. 7-38.

NOLLAND, C. Agency and embodiment. Cambridge: Havard University Press, 2009.

OCHOA, M. Ciudadanía perversa: divas, marginación y participación en la 'localización'. In: MATO, D. (Coord.). Políticas de ciudadanía y sociedad civil en tiempos de globalización. Caracas: FACES, Universidad Central de Venezuela, 2004. p. 239-256.

OLIVEIRA, T. R. M.; SANTOS, C. Novos mapas de (trans)sexualidade e gênero: políticas trans e práticas pedagógicas. Revista Cronos, Natal, v. 11, n. 2, p. 97-117, 2010.

PETER, M.; BURBULES, N. Postestructuralism and educational research. Oxford: Rowman \& Littlefield, 2004.

PINAR, W. What is curriculum theory? Mahwah, Nova Jersey: Lawrence Erlbaum Associates Publisers, 2004.

PRECIADO, B. Manifiesto contra-sexual. Madrid: Opera Prima, 2002.

PLUMMER, K. Critical humanism and queer theory: living with the tensions. In: DENZIN, N.; LINCOLN, Y. The Landscape of Qualitative Research. London: Sage, 2005. p. 357-373.

PRIGOGINE, I. Enciclopédia Einaudi. Lisboa: Imprensa Nacional, 1993.

PRIGOGINE, P.; STENGERS, I. La sorcellerie capitaliste. Paris: La Découverte, 2005.

PUAR, J. Queer times, queer assemblages. Social Text [online], v. 23, n. 3-4, n. 84-85, p. 121-139, 2005. DOI 10.1215/01642472-23-3-4_84-85-121

RABINOW, P. Making time. Princeton: University Press, 2008.

REIS, C. D. O uso da metodologia queer em pesquisa no campo do currículo. In: PARAÍSO, M. A.; MEYER, D. E. (Orgs.). Metodologias de pesquisas pós-críticas em educação. Belo Horizonte: Mazza, 2012. p. 247-264.

RIZVI, F. Virtudes epistêmicas e aprendizagem cosmopolita. Teias, Rio de Janeiro, v. 11, n. 22, p. 165-196, maio/ago. 2010.

RIZVI, F; LINGARD, B. Globalizing education policy. Nova York: Routledge, 2010.

ROOKE, A. Queer in the field: On emotions, temporality and performativity in Ethnography. BROWNE, K.; NASH, C. (Orgs). Queer methods and methodologies. London: Asghate, 2010. p. 25-40.

SCOTT, J. Experiência. In: SILVA, A. L.; LAGO, M. C. S.; RAMOS, T. R. O. Falas de gênero. Florianópolis: Mulheres, 1999.

SEDGWICK, E. Epistemology of closet. Los Angeles: University of California Press, 1990.

SEDGWICK, E. Queer performativity: Henry James's The Art of the Novel. GLQ [online], v. 1. n. 1, p. 1-16, 1993. DOI: 10.1215/10642684-1-1-1

SEDGWICK, E. Touching feeling. Duke: Duke University Press, 2003.

Práxis Educativa, Ponta Grossa, v. 11, n. 2, p. 332-356, maio/ago. 2016 Disponível em: <http://www.revistas2.uepg.br/index.php/praxiseducativa> 
SPARGO, T. Foucault e a teoria queer. Rio de Janeiro: Pazulin, 2006.

SPIVAK, G. In other worlds. New York: Routledge, 2006.

ST. PIERRE, E. A. Afterword: descentering voice in the qualitative inquiry. In: JACKSON, A; MAZZEI, L. (Orgs.). Voice in qualitative inquiry. New York: Routledge, 2008. p. 221-236. DOI: $10.1177 / 1532708613487862$

ST. PIERRE, E. A. The appearance of data. Cultural studies: critical methodologies [online], $\mathrm{n}$. 13, v. 4, p. 223-227, 2013.

STRATHERN, M. The Limits of Auto-Anthropology. In: JACKSON, A. (Ed.). Anthropology at home. London: Tavistock Publications, 1987. p. 59-67.

STRATHERN, M. Property substance and effect. London: Athlone Press, 1999.

STRYKER, S. (De)Subjugated Knowledges. In: STRYKER, S.; WHITTLER, S. (Orgs.). The transgender studies. New York: Routledge, 2006. p. 1-19.

VALOCCHI, S. Not yet queer enough: The lessons of queer theory for the sociology of gender and sexuality. Gender and Society [online], v. 19, n. 6, p. 750-770, 2005. DOI: $10.1177 / 0891243205280294$

VEIGA-NETO, A.; LOPES, M. C. Identidade, cultura e semelhanças de família: as contribuições da virada lingüística. In: BIZARRO, R. (Org.). Eu e o outro: estudos multidisciplinares sobre Identidade(s), Diversidade(s) e Práticas Interculturais. Porto (Portugal): Areal, 2007. p. 175-190.

VEIGA-NETO, A.; MACEDO, E. Estudos de currículo: como lidamos com os conceitos de moderno e pós-moderno. Educação Temática Digital, Campinas, v. 9, n. esp., p. 234-252, out. 2008.

VIANA, A. C. No meio do mundo e outros contos. São Paulo: Companhia das Letras, 1999.

VILLAREJO, A. Tarrying with the normative: queer theory and black history. Social Text [online], v. 23, n. 3-4, p. 69-84, 2005. 